ISSN: 1907-9931 (print), 2476-9991 (online)

\title{
KOMPARASI INDEKS KEANEKARAGAMAN DAN INDEKS DOMINANSI FITOPLANKTON DI SUNGAI CILIWUNG JAKARTA COMPARISON OF DIVERSITY INDEX AND DOMINANT INDEX OF PHYTOPLANKTON AT CILIWUNG RIVER JAKARTA
}

\author{
Marlenny Sirait ${ }^{{ }^{*}}$, Firsty Rahmatia ${ }^{1}$, Pattulloh $^{2}$ \\ ${ }^{1}$ Fakultas Perikanan dan IImu Kelautan, Universitas Satya Negara Indonesia \\ ${ }^{2}$ Badan Karantina Ikan dan Pengendalian Mutu Perikanan, KKP RI \\ *Corresponding author e-mail: lenny.uline@gmail.com
}

Submitted: 20 November 2017 / Revised: 02 November 2018 / Accepted: 02 November 2018

http://doi.org/10.21107/jk.v11i1.3338

\begin{abstract}
Phytoplankton is a biological parameter that can be used as an indicator to evaluate the quality and level of fertility of a water. Changes in water quality as a result of the large load of nutrients entering the Ciliwung River will affect the life of phytoplankton. This study aims to see the comparative index of diversity $\left(H^{\prime}\right)$ and the Dominant Index $(D)$ of phytoplankton in Ciliwung River from upstream to downstream. The study was conducted from December 2016 to February 2017 from upstream to downstream of the Ciliwung River. From the index analysis of diversity and index of dominance, there was a significant difference, where the downward index of diversity $(H$ ') of phytoplankton was lower, ranged between 1,21 and 2,6 (the index of diversity ranging from low to medium). Otherwise, the dominance index showed the opposite result. The more downstream the dominance index is higher than the upstream, ranged between 0,09 and 0,68. Thus the index of diversity and the index of phytoplankton dominance has a relationship inversely. Differences of diversity index and dominance index in upstream to downstream poses an imbalance of ecosystem in Ciliwung River.
\end{abstract}

Keywords: Ciliwung, diversity index, Dominant Index, Phytoplankton

\begin{abstract}
ABSTRAK
Fitoplankton merupakan parameter biologi yang dapat dijadikan sebagai indikator untuk mengevaluasi kualitas dan tingkat kesuburan suatu perairan. Perubahan kualitas perairan sebagai akibat banyaknya beban nutrien yang masuk ke sungai Ciliwung akan berpengaruh terhadap kehidupan fitoplankton. Penelitian ini bertujuan untuk melihat komparasi indeks keanekaragaman ( $\left.H^{\prime}\right)$ dan Indeks Dominansi (D) fitoplankton di Sungai Ciliwung dari hulu sampai hilir. Penelitian dilaksanakan pada bulan Desember 2016 sampai Februari 2017 dari mulai hulu sampai hilir Sungai Ciliwung. Dari analisis indeks keanekaragaman dan indeks dominansi diperoleh perbedaan yang nyata, dimana semakin ke hilir indeks keanekaragaman $\left(H^{\prime}\right)$ fitoplankton semakin rendah dengan kisaran 1,21 sampai dengan 2,6. Sebaliknya, indeks dominansi menunjukkan hasil bahwa semakin ke Hilir indeks dominasi lebih tinggi dibandingkan dengan bagian hulu dengan kisaran 0,09 sampai dengan 0,68. Dengan demikian indeks keanekaragaman dan indeks dominansi fitoplankton memiliki hubungan berbanding terbalik. Perbedaan indeks keanekaragaman dan indeks dominansi di sepanjang aliran hulu sampai hilir mengakibatkan terjadinya ketidakseimbangan ekosistem di Sungai Ciliwung.
\end{abstract}

Kata Kunci: Ciliwung, indeks keanekaragaman, Indeks Dominansi, Fitoplankton

\section{PENDAHULUAN}

Sungai Ciliwung termasuk DAS kritis di Indonesia yang saat ini sedang mengalami kerusakan serius pada semua segmen sungainya. Degradasi kualitas DAS Ciliwung dari hulu hingga hilir selain mengakibatkan adanya bencana banjir, menurunnya kualitas air sungai dengan status tercemar berat dari hulu hingga hilir, serta hilangnya keanekaragaman hayati di Sungai Ciliwung. Buruknya kualitas air tersebut menyebabkan 
kepunahan biota air di Sungai Ciliwung (laju kehilangan jenis asli crustacea $67 \%$, mollusca $66 \%$ dan ikan sebesar $92 \%$ ).

Fitoplankton merupakan parameter biologi yang dapat dijadikan sebagai indikator untuk mengevaluasi kualitas dan tingkat kesuburan suatu perairan. Fitoplankton juga merupakan penyumbang oksigen terbesar di dalam suatu perairan. Pentingnya peranan fitoplankton sebagai pengikat awal energi matahari menjadikan fitoplankton berperan penting bagi kehidupan perairan (Fachrul, 2005). Perubahan kualitas perairan sebagai akibat banyaknya beban nutrien yang masuk ke sungai Ciliwung akan berpengaruh terhadap kehidupan fitoplankton. Kompleksnya rantai makanan (food Chain) dan jaring makanan (foodweb) serta pentingnya fitoplankton sebagai produsen primer akan memberikan pengaruh yang sangat besar dalam dinamika ekosistem di Sungai Ciliwung. Semakin stabil lingkungan perairan maka akan secar langsung berpergaruh terhadap kestabilan komunitas plankton. Keberadaan fitoplankton sangat berpengaruh terhadap kelangsungan hidup ikn dan larva perairan.

Kestabilan komunitas lingkungan perairan di Sungai Ciliwung dapat dianalisis melalui komparasi indeks keankeragaman dan Indeks Dominansi fitoplankton, untuk itu penelitian ini dilakukan untuk membandingkan indeks keanekaramagaman dan indeks domninasi fitoplankton di Sungai Ciliwung dari mulai hulu sampai hilir.

\section{MATERI DAN METODE Waktu dan Tempat}

Penelitian dilaksanakan pada bulan Desember 2016 sampai dan Februari 2017. Lokasi penelitian di sepanjang aliran Sungai Ciliwung, mulai dari hulu di daerah Jembatan Gadog, Jawa Barat, hingga hilir/muara di Teluk Gong, selengkapnya stasiun pengambilan sampel dan kualitas air dapat dilihat dalam Tabel berikut ini:

Tabel 1 Lokasi Stasiun Pengambilan Sampel Fitoplankton dan Kualitas Air

\begin{tabular}{|c|c|c|c|}
\hline No & Segmen & Titik Koordinat & Lokasi \\
\hline 1 & \multirow{3}{*}{ I } & $06^{\circ} 39^{\prime} 8.97^{\prime \prime}, 106^{\circ} 52^{\prime} 7.67^{\prime \prime}$ BT & Jembatan Gadog \\
\hline 2 & & $06^{\circ} 33^{\prime} 45.71 " \mathrm{LS}, 106^{\circ} 52^{\prime} 14.24 " \mathrm{BT}$ & Gadog \\
\hline 3 & & $06^{\circ} 37^{\prime} 59.34^{\prime \prime L S}, 106^{\circ} 50^{\prime} 13.41^{\prime \prime B T}$ & Katulampa \\
\hline 4 & \multirow{3}{*}{ II } & $06^{\circ} 37^{\prime} 59.34^{\prime \prime L S}, 106^{\circ} 50^{\prime} 13.41^{\prime \prime B T}$ & Kelapa Dua \\
\hline 5 & & $06^{\circ} 15^{\prime 29,3 " ~ L S, ~} 106^{\circ} 51 ' 38,3^{\prime \prime}$ BT & Kalibata \\
\hline 6 & & $06^{\circ} 13^{\prime} 34,4^{\prime \prime}$ LS , $106^{\circ} 51$ '51,3" BT & Kampung Melayu \\
\hline 7 & \multirow{3}{*}{ III } & $06^{\circ} 12^{\prime} 15^{\prime \prime}$ LS $106^{\circ} 50^{\prime} 17,5^{\prime \prime}$ BT & Pejompongan \\
\hline 8 & & $06^{\circ} 10^{\prime 2} 23^{\prime \prime}$ LS $106^{\circ} 48^{\prime} 26^{\prime \prime}$ BT & K.H Mas Mansyur \\
\hline 9 & & $06^{\circ} 08^{\prime} 31^{\prime \prime ~ L S ~} \quad 106^{\circ} 45^{\prime 2} 28^{\prime \prime}$ BT & Teluk Gong \\
\hline
\end{tabular}

Metode yang digunakan dalam penelitian ini adalah metoda survey pada 9 stasiun yang telah ditentukan dengan menggunakan GPS. Pengambilan sampel fitoplankton menggunakan plankton net nomor 25 dengan cara menyaring air sebanyak $100 \mathrm{~L}$. Pengambilan air dilakukan secara komposit pada tiga titik sampel yang mewakili bagian tengah, tepi kiri, dan tepi kanan sungai. Fitoplankton yang terkumpul pada botol konsentrat pada plankton net dipindahkan ke dalam botol sampel serta diberi bahan pengawet Lugol sebanyak \pm 10 tetes (APHA, 1995). Sampel fitoplankton kemudian dicacah menggunakan Sedgwick-Rafter Cell, yaitu berupa gelas preparat berbentuk empat persegi panjang (APHA, 1995). Jenis-jenis fitoplankton yang terdapat di perairan Sungai Ciliwung diamati dengan mikroskop dan diidentifikasi menggunakan buku dari Edmondson (1963) dan Mizuno (1978).
Analisa data dilakukan dengan cara penghitungan Indeks Keanekaragaman (Diversity Index/H') dan Indeks Keseragaman (Equitability Index/E) dengan formula sebagai berikut:

a. Indeks Keanekaragaman $\left(\mathrm{H}^{\prime}\right)$

$$
H^{\prime}=-\sum_{i=1}^{n} p i \ln p i
$$

keterangan:

$$
\begin{aligned}
& \mathrm{H}^{\prime}=\text { indeks keanekaragaman } \\
& \mathrm{Pi}=\mathrm{ni} / \mathrm{N} \\
& \mathrm{Ni}=\text { jumlah individu jenis ke- } \mathrm{i} \\
& \mathrm{N}=\text { jumlah total individu semua jenis }
\end{aligned}
$$

Kisaran indeks keanekaragaman (Shannon Weiner, 1949)

2,3026

=keanekaragaman kecil dan kestabilan komunitas rendah

$2,3026<\mathrm{H}^{\prime} \quad=$ keanekaragaman sedang dan

$<6,9078$ kestabilan komunitas sedang 
$\mathrm{H}^{\prime}>$ 6,9078=keanekaragaman tinggi dan kestabilan komunitas tinggi

b. Indeks Keseragaman (E')

$$
E=\frac{H^{\prime}}{H_{\text {maks }}}
$$

Keterangan :

$$
\begin{aligned}
& \mathrm{E} \quad=\text { indeks keseragaman } \\
& \text { Hmaks = In } \mathrm{S} \\
& \mathrm{S} \quad=\text { jumlah spesie }
\end{aligned}
$$

Kisaran indeks keseragaman (Magurran, 1982):

$$
\begin{array}{ll}
\mathrm{E} & =0-1 ; \\
\mathrm{E} & \begin{array}{l}
\text { =sebaran individu antar jenis tidak } \\
\text { mendek } \\
\text { merata/ada jenis tertentu yang dominan }
\end{array} \\
\text { ati } 0 & \\
\mathrm{E} & =\text { sebaran individu antar jenis merata } \\
\text { mendek } &
\end{array}
$$

c. Indeks Dominansi (D)

Indeks Dominansi dihitung dengan menggunakan rumus indeks dominanasi dari Simpson (Odum, 1993):

Keterangan:

$$
\mathrm{D}=\Sigma(\mathrm{ni} / \mathrm{N})^{2}
$$

$$
\begin{aligned}
& \mathrm{D}=\text { Indeks Dominansi Simpson } \\
& \mathrm{Ni}=\text { Jumlah Individu tiap spesies } \\
& \mathrm{N}=\text { Jumlah Individu seluruh spesies }
\end{aligned}
$$

Indeks dominansi berkisar antara 0 sampai 1 , dimana semakin kecil nilai indeks dominansi maka menunjukan bahwa tidak ada spesies yang mendominsi sebaliknya semakin besar dominansi maka menunjukkan ada spesies tertentu (Odum, 1993).

\section{HASIL DAN PEMBAHSAN}

Berdasarkan hasil perhitungan, komparasi Indeks Keanekaraman (Diversity Index/H') rata-rata fitoplankton di 9 (sembilan) titik pengambilan sampel di Sungai Ciliwung masuk dalam kategori rendah sampai sedang. Sedangkan Indeks Keseragaman masuk dalam sebaran individu antar jenis tidak merata sampai kondisi sebaran individu antar jenis merata. Rata-rata Indeks Keanekaraman (Diversity Index/H') berada diantara 1,21 sampai 2,6 atau indeks keanekaragaman mulai dari rendah sampai sedang. Berdasarkan Gambar 1 Indeks Keanekaragaman Fitoplankton dijumpai di segmen I mulai dari Pejampongan, K.H Mas Mansyur dan Teluk Gong. Stasiun K.H Mas Mansyur merupakan stasiun yang indeks keanekaragaman paling rendah sebesar 1,21, diikuti Pejampongan $(1,48)$ dan Teluk Gong $(1,48)$. Menurut Shannon-Weiner (1949), bahwa $H^{\prime}<2,3026$ menunjukkan indeks keanekaragaman kecil dan kestabilan komunitas rendah. Rendahnya Indeks Keanekeragaman $\left(\mathrm{H}^{\prime}\right)$ diduga disebabkan oleh kondisi perairan yang sangat tidak baik. Hal ini terlihat dari kondisi fisik warna air yang berwarna hitam dan perairan yang dangkal karena banyaknya endapan di dasar sungai. Aktivitas di sekitar sungai yang berupa perumahan, kantor, dan perdagangan banyak membuang limbah ke perairan sungai. Buangan tersebut menyebabkan kondisi unsur hara perairan menjadi tidak seimbang, sehingga tidak mendukung keoptimalan pertumbuhan fitoplankton. Romimoharto dan Juwana (2004), menyebutkan kekeruhan air adalah jumlah padatan tersuspensi dalam suatu perairan, sedangkan kecerahan adalah daya tembus cahaya matahari kesuatu perairan, dalam hal ini adalah jarak tembus cahaya kedalam suatu perairan.

Jika dilihat dari distribusi kehadiran fitoplankton di segmen I, kehadiran fitoplankton di K.H. Mas Mansyur sangat rendah dibandingkan dengan stasiun Pejompongan dan Teluk Gong. Kehadiran spesies yang mendominasi di ketiga stasiun ini adalah spesies Cyclotella sp. dari kelas Bacillariophyceae. Hadirnya populasi dari Cyclotella $s p$ dalam jumlah yang besar dapat mempengaruhi keseimbangan populasi dalam suatu komunitas. Hal ini juga diperkuat oleh Barange dan Campos (1991) menjelaskan bahwa adanya dominansi memperlihatkan adanya persaingan atau kompetisi dalam pemanfaatan sumber daya dan kondisi lingkungan perairan yang tidak seimbang atau tertekan.

Indeks keanekaragaman termasuk dalam kategori sedang dijumpai di Jembatan Gadog sampai Kampung Melayu dengan nilainya termasuk dalam 2,3026 < $\mathrm{H}^{\prime}<6,9078$. Indeks Keanekaragaman tertinggi dijumpai di stasium Katulampa sebesar 2,60 dan diikuti oleh stasiun Jembatan Gadog dan Kelapa Dua. Kondisi ini menunjukkan bahwa produktivitasnya sedang, kondisi ekosistem sedang, meskipun terdapat indikasi adanya tekanan ekologi.

Nilai Indeks Keseragaman (E') terendah ditemukan di segmen 3 (Pejampongan, K.H Mansur dan Teluk Gong) dimana nilai E' berkisar antara 0,42 samapi 0,45 . Sesuai dengan Kisaran indeks keseragaman (Magurran, 1982) menyatakan sebaran individu antar jenis tidak merata/ada jenis tertentu yang dominan. Hal ini juga berkorelasi dengan rendahnya Indeks Keanekaragaman $\left(H^{\prime}\right)$ pada stasiun ini. Gambar 1 menujukkan 
semakin tinggi indeks Keanekaragaman $\left(\mathrm{H}^{\prime}\right)$ maka Indeks Keseragaman (E') semakin mendekati 0 (nol). Adanya perbedaan nilai indeks keanekaragaman dan keseragaman yang bervariasi pada perairan menurut Yazwar (2008), disebabkan oleh faktor fisika air serta ketersediaan nutrisi dan pemanfaatan nutrisi yang berbeda dari tiap individu. Ketersediaan nutrisi seperti pospat dan nitrat, serta kemampuan dari masing-masing jenis fitoplankton untuk beradaptasi dengan lingkungan yang ada.

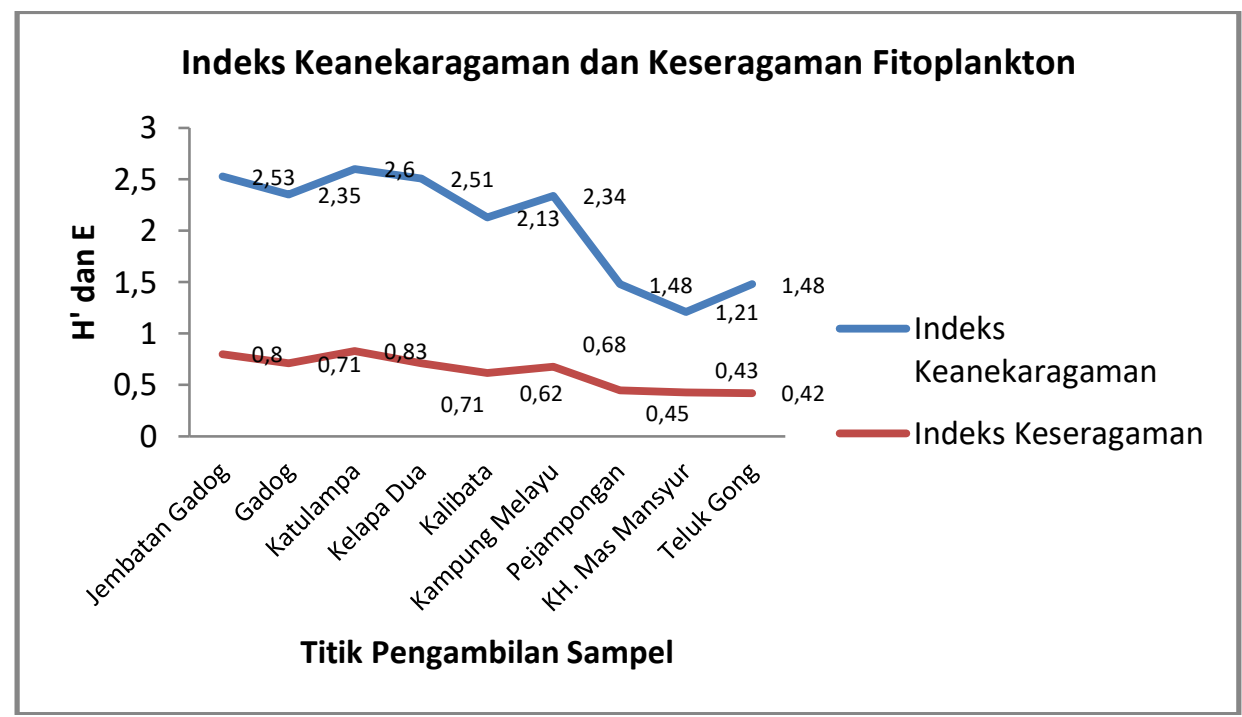

Gambar 1. Indeks Keanekragaman (H') dan Keragaman (E') Fitoplankton di Sungai Ciliwung

Berdasarkan Gambar 1 di atas menunjukkan bahwa semakin ke hilir indeks Keanekaragaman $\left(\mathrm{H}^{\prime}\right)$ fitoplankton semakin rendah. Demikian juga indeks keseragaman (E') fitoplankton semakin rendah mendekati 0 (nol). Kondisi ini menggambarkan bahwa ekosistem Sungai Ciliwung semakin ke hilir menujukkan rendahnya kualitas perairan.

Indeks Dominansi (D) rata-rata di 9 (sembilan) titik pengambilan sampel berada pada kategori berkisar antara 0,09 sampai 0,68. Berdasarkan gambar 2 menunjukkan bahwa dari semua stasiun pengambilan sampel, segmen III (Pejampongan, K.H Mansyur dan Teluk Gong) dijumpai tingkat dominansi tertinggi dibandingkan dengan segmen II dan segmen III. Semakin ke hilir indeks dominasi semakin tinggi, dimana semakin kecil nilai indeks dominansi maka menunjukan bahwa tidak ada spesies yang mendominsi sebaliknya semakin besar dominansi maka menunjukkan ada spesies tertentu (Odum, 1993).

Dilihat dari komposisi jenis fitopalankton di ketiga stasiun ini cukup beragam. Kelas fitoplankton yang mendominasi masih dari kelas Bacillariophyceae sebanyak 70,59\%, diikuti oleh kelas Clorophyceae sebanyaak $42,89 \%$, Euglenophyceae sebanyak $11,76 \%$ Cyanophyceae sebanyak $11,43 \%$ dan terendah adalah kelas Dinophyceae sebanyak
2,86\%. Dominansi spesies Cyclotella sp. dari kelas Bacillariophyceae memiliki dominansi yang cukup besar yang mengarah kepada komunitas yang labil dan tertekan.

Segmen II (Kelapa Dua, Kalibata, Kampung Melayu) merupakan perwakilan bagian tengah dari Sungai Ciliwung. Indeks Dominansi (D) di segmen ini lebih rendah di bandingkan dengan segmen III. Hal ini diduga kondisi kualitas perairan yang masih baik dibandingkan dengan segmen III. Sedangkan segmen I (Jembatan Gadog, Gadog dan Katulampa) tingkat dominansi lebih rendah jika dibandingkan dengan segmen II (Kelapa Dua, Kalibata, Kampung Melayu). Stasiun Katulampa memiliki tingkat dominansi paling rendah sebesar 0,09 , nilai yang paling mendekati 0 (nol). Angka ini menujukkan bahwa ada spesies yang mendominasi dalam ekosistem sungai Ciliwung. Berdasarkan hasil pengamatan di segmen I fitoplankton didominasi oleh spesies Spirulina sp. dari kelas Cyanophyceae dan Nitzschia sp. dari kelas Bacillariophyceae. Spirulina $s p$. merupakan mikroalga yang memiliki adaptasi tinggi, yang mampu tumbuh dalam berbagai kondisi pertumbuhan, sedangkan Nitzschia $s p$. yang ditemukan pada stasiun ini juga mengindikasikan bahwa perairan tersebut berada pada kondisi eutrofik-hipereutrofik (Soeprobowati, 2011). 


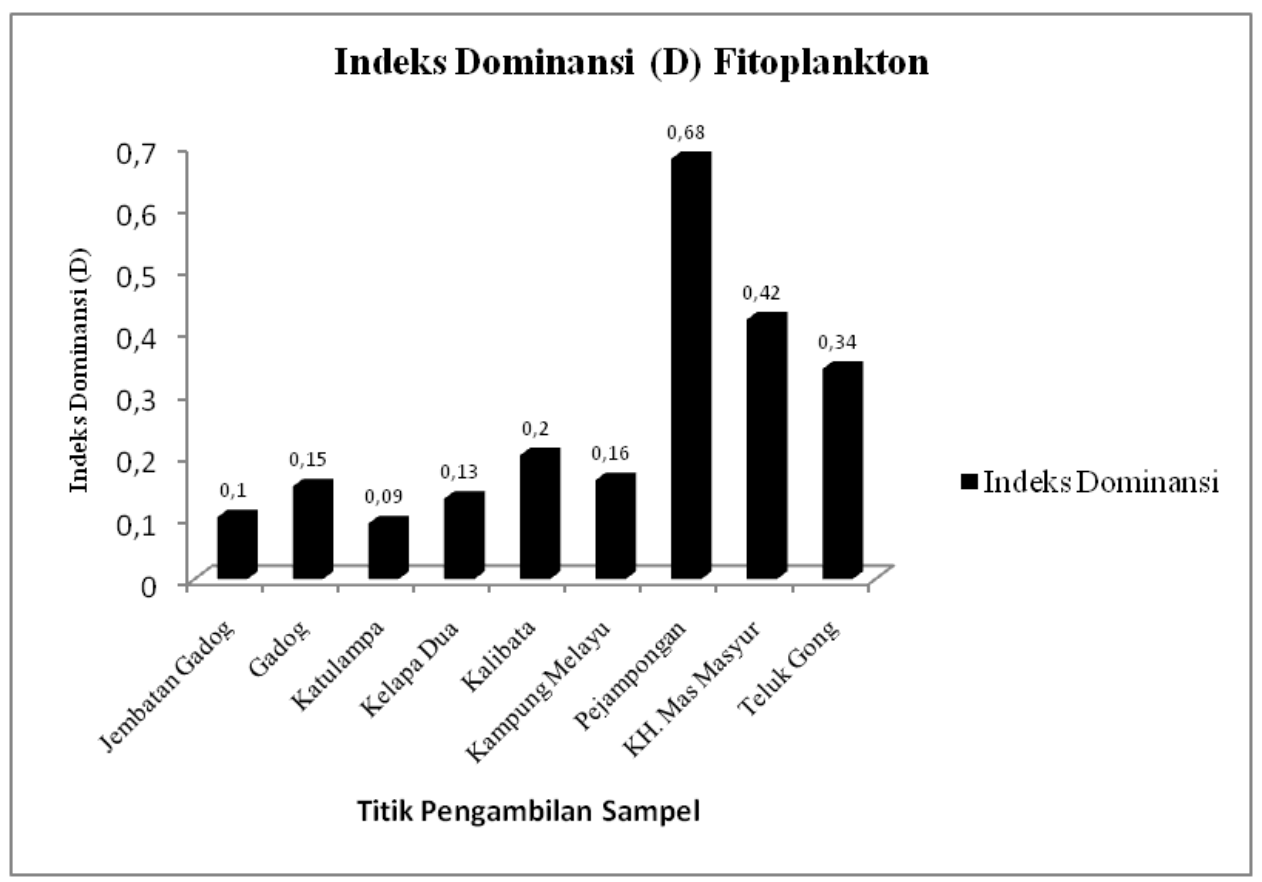

Gambar 2. Indeks Dominansi (D) di Sungai Ciliwung

\section{KESIMPULAN DAN SARAN}

Berdasarkan penelitian yang dilakukan diperoleh kesimpulan bahwa komparasi indeks Keanekaragaman di perairan Sungai Ciliwung menujukkan bahwa indeks Keanekaragaman di hulu (jembatan Gadog, Gadog dan Katulampa) lebih tinggi sebesar 2,6 dibandingkan dengan bagian hulu sebesar 1,48 . Hal ini berkorelasi terbalik dengan Indeks Dominansi. Semakin ke Hilir Indeks dominasi lebih tinggi sebesar $(0,68)$ dibandingkan dengan bagian hulu $(0,09)$.

\section{DAFTAR PUSTAKA}

APHA. (1976). Standard Methods for the Examination of Water and Wastewater 14ed. APHA American Public Health Association.

Barange, M., \& Campos, B. (1991). Models of species abundance: A critique of and an alternative to the dynamics model. Marine ecology progress series. Oldendorf, 69(3), 293-298.

Edmondson, W.T. (1963). Freshwater Biology. 2nd ed. New York: John Wileyand Son.

Fachrul, M. F. (2005). Komunitas fitoplankton sebagai bio-indikator kualitas perairan Teluk Jakarta (Phytoplankton community as a bio-indicator for quality of Jakarta waters). In Proceeding Seminar Nasional MIPA (pp. 17-23).

Odum, E. P. (1993). Dasar-Dasar Ekologi. Penerjemah: Tjahyono Samingan.
Pitcher, T. J., Magurran, A. E., \& Winfield, I. J. (1982). Fish in larger shoals find food faster. Behavioral Ecology and Sociobiology, 10(2), 149-151.

Romimohtarto, K., \& Juwana, S. (2004). Meroplankton laut: larva hewan laut yang menjadi plankton. Djambatan. Jakarta. $191 \mathrm{hlm}$.

Shannon, C. E., \& Weaver, W. (1949). The mathematical theory of communication., (The University of Illinois Press: Urbana, IL, USA).

Yazwar. 2008. Keanekaragaman Plankton dan Keterkaitannya dengan Kualitas Air di Parapat Danau Toba.Medan: Tesis Sekolah Pascasarjana Universitas Sumatera Utara. 